\title{
IMPLANT SUPPORTED PARTIAL OVERDENTURE IN ESTHETIC ZONE (PRELIMINARY REPORT)
}

\author{
Ehab A. Elsaih*, Ahmed S. Salem ${ }^{* *}$ and Bassant Mowafey ${ }^{* * *}$
}

\begin{abstract}
Purpose: This study aimed to investigate the implant-supported removable partial denture in the aesthetic zone with different attachments regarding the patient's opinion, and health of soft and hard tissue related to the implants.
\end{abstract}

Materials and Methods: Eight subjects missing four/five maxillary anterior teeth were enrolled for this work in two groups according to the attachment used. Each patient had a removable prosthesis with attachment (positioner and ball) on two implants. Visual analog scale (VAS), marginal bone level, gingival index (GI), implant stability, and peri-implant propping depth (PD) were evaluated for all subjects in a scheduled 6 and 12 months follow-up.

Results: VAS showed a significant difference indicating better patient acceptance to the implant-supported prosthesis and improved quality of life. No implant failure was recorded, and a mean marginal bone loss was $0.66 \pm 0.10$ in group A and $0.70 \pm 0.09$ in group B. No statistically significant difference between groups in all study periods for gingival probing depth (PD) and implant stability. The gingival index (GI) showed a significant difference in ball attachment group $\mathrm{B}$ in the 12 months period.

Conclusion: Within the limitation of this work, the removable partial overdenture can be used (when indicated) in the anterior region with anticipated success independent of the type of attachments

KEYWORDS: Aesthetic zone, anterior teeth replacement, removable partial overdenture, implant-supported prosthesis, positioner versus ball attachment

\section{INTRODUCTION}

Challenging demands in maxillary anterior teeth replacement are the need for immediacy, esthetic satisfaction, and functionality. However, the matching of patient desire and treatment outcome is always governed by the patient's clinical parameters and financial feasibility ${ }^{(1,2)}$.

* Associate Professor of Removable Prosthodontics, Faculty of Dentistry, Mansoura University.

** Associate Professor of Oral and Maxillofacial Surgery, Faculty of Dentistry, Mansoura University.

*** Lecturer of Diagnosis and Oral Radiology, Oral Medicine, Periodontology, Diagnosis and Oral Radiology

Department, Faculty of Dentistry, Mansoura University 
The implant-supported prosthesis, the fixedpartial prosthesis and the removable partial prosthesis, are the anterior replacement modalities that are preferred in their respective order. But the patient preference should be guided by the diagnostic criteria which indicate or contra-indicate the patient's choice $^{(3)}$.

At the beginning of the new millennium, dental implants had been proved for highly successful outcomes through a lot of researches \& clinical trials. Advances in implant designs and surface treatments provoked the dental professions to use implants to seek optimal results in each difficult clinical situation ${ }^{(4)}$.

Achieving success in anterior teeth replacement drew the attention of clinicians. In the esthetic area, the prosthetic driven implant placement replaced the implant driven concept to provide integration with desired esthetics \& function ${ }^{(5)}$.

Fixed implant prosthetic option is primer option, but this is true if all clinical parameters are favorable but limitations as the bone quality, quantity, orientation, and sometimes proximity to vital regions may affect reasonable implant number and direction in bone ${ }^{(3)}$. Also, the diagnostic wax-up, facial support, and lip criteria (length, thickness, and display) as well as many other crucial diagnostic factors that when collected and carefully interpreted the resulting prosthetic decision may not be a fixed prosthesis ${ }^{(6,7)}$.

Maxillary anterior removable replacement prosthesis may help to avoid complex surgical interference to modify bone including augmentation of soft or hard tissues or sinus elevation ${ }^{(8)}$. And sometimes deemed necessary, provoked by clinical parameters, to meet prosthetic needs and patient esthetic demands ${ }^{(5)}$.

The concept of claspless partial removable prosthesis in the esthetic zone has been presented in case presentations and preliminary reports investigating implant tissue health and radiographic bone level ${ }^{(9,10)}$. But the success of that treatment option and type of attachment to be used in cases with minimal implant number need investigation. And due to limited or even scarce studies in this category, this work is considered a pilot attempt to understand its aspects as patient acceptance and the possibility of clinical success.

\section{MATERIAL AND METHODS}

The work regime and protocol were laid according to ethical guidelines listed and approved by the local ethics committee, college of dentistry, Mansoura University (A13080921). Each patient was asked to sign informed consent according to the approved regulations before clinical procedures.

\section{Patient selection criteria}

Eight subjects were selected according to the following inclusion criteria: a) Kennedy class IV partially edentulous maxilla (missing 4-5 anterior teeth) (fig. 1a), b) pre-operative CBCT was used to assess the presence of alveolar bone of acceptable length \& diameter to receive dental implants with a D2 or D3 bone density ${ }^{(\mathbf{1 1})}$, and free of remaining pathology, c) no history of previous tissue augmentation for mucosa or bone, d) reasonable vertical bone level discrepancy (not more than $2 \mathrm{~mm}$ ), e) indicated partial or complete flanged removable prosthesis (short lip, defect in facial support), f) lack of enough implant number (according to bone volume and configuration), g) controlled oral hygiene, h) patient desire for treatment modality other than conventional removable prosthesis and willingness to give informed consent.

The following exclusion criteria were considered: a) absence of active periodontal disease or any defective restoration nearby the edentulous site, $b$ ) bruxism or other para-functional habits, c) abnormal lower anterior teeth position (over eruption) or relation (class III malocclusion), d) abnormal eccentric teeth relation or unstable posterior 
occlusion (minimal posterior intercuspation), e) smoking more than 10 cigarettes per day, f) arch configuration that deems necessity of base labial extension or artificial teeth labial inclination which creates a cantilever situation more than $2-3 \mathrm{~mm}$ in horizontal direction off-ridge, g) presence of bone affecting diseases and medications that might compromise the osseointegration. These parameters of the participants were shown in Table 1 .

\section{Prosthetic diagnosis \& planning}

Final impressions were made, poured and the cast was mounted on a semi-adjustable articulator using maxillary face bow and wax inter-occlusal record. Diagnostic wax-up was constructed to get an idea about the amount of facial support, labial teeth display, inter arch contact-free relation, and amount of mesial cantilever (teeth arch/residual ridge relation).
Facial rubber base index was constructed then wax-up was processed into temporary acrylic partial prosthesis (intra-oral frictionally fit to neighboring teeth with partial palatal extension) and the preoperative CBCT was used to construct a CADCAM stereolithographic surgical template ${ }^{(12)}$ to assist oriented implant installation. Patients with low bone density ( $\leq 300$ Hounsfield Units) were excluded from the study ${ }^{(13,14)}$.

\section{Surgical Procedure}

The same flapless surgical protocol was applied to all patients ${ }^{(15)}$, where two implants of $10-12 \mathrm{~mm}$ length (Implantum II, Dentium Co., Seoul, Korea) were installed using the surgical guide stent in both sides of mid-line with 12-16 mm distance apart (according to local bone availability) and acceptable primary implant stability (PIS) ${ }^{(16)}$.

TABLE (1) Descriptive data of the selected participants in each group.

\begin{tabular}{|c|c|c|c|}
\hline Criteria & GB & GA & Total \\
\hline Gender (male/ female) & $3 / 1$ & $2 / 2$ & $5 / 3$ \\
\hline Age (years) & $40.5 \pm 4$ & $42 \pm 2.5$ & $41 \pm 3.4$ \\
\hline Previous RPDs (No.) & $1.5 \pm 0.8$ & $1.2 \pm 0.6$ & $1.3 \pm 0.5$ \\
\hline Previous RPD/s (years) & $3.7 \pm 0.5$ & $3.9 \pm 0.3$ & $3.8 \pm 0.4$ \\
\hline Number of missing teeth $(4 / 5)$ & $4 / 0$ & $3 / 1$ & $7 / 1$ \\
\hline Smoking status (nonsmoker / smoker $\leq 10$ per day) & $4 / 0$ & $3 / 1$ & $7 / 1$ \\
\hline Vestibular extension (Partial / full) & $3 / 1$ & $2 / 2$ & $5 / 3$ \\
\hline Palatal extension Cover rougee area / beyond residual ridge & $4 / 0$ & $1 / 3$ & \\
\hline Major connector Acrylic / combined metal \& acrylic & $4 / 0$ & $3 / 1$ & $7 / 1$ \\
\hline Implant attachment & Ball attachment & Positioner & - \\
\hline Implant length (mm) & $10-12$ & $10-12$ & $10-12$ \\
\hline Implant diameter (mm) & $3.7-4$ & $3.7-4$ & $3.7-4$ \\
\hline
\end{tabular}

$G A=$ positioner group,$G B=$ ball group 
Healing abutments of gingival cooler height G/H 2.0 were screwed-in and the temporary partial removable prosthesis was generously relieved corresponding to healing abutments then refitted by a soft liner (Softliner, GC Corporation, Tokyo, Japan), and occlusion was inspected for free protrusive movement ${ }^{\left({ }^{17}\right)}$. Patients were instructed to avoid biting on the anteriors.

\section{Final prosthesis}

After eight weeks ${ }^{(\mathbf{1 8}, \mathbf{1 9})}$, the healing abutments were removed and the site was cleaned using chlorohexidine anti-bacterial solution (Ultradent Products, Inc.). A final maxillary impression (fig. 1b) was made using closed tray impression copings and poured to get analog containing stone cast. The healing abutments were re-attached.

Patient casts were mounted on a semi-adjustable articulator using a wax inter-occlusal record. The cases were randomly assigned into two groups of four patients each, Group A with positioner attachment and Group B with ball attachment chartered as follows; (a- positioner width $\varnothing 3$. and b- mini-ball with ball/ base width " $1.8 \varnothing / 2.8 \varnothing$ ") with gingival cooler height G/H 2.0-3.0 (fig. 2a,2b,3a,3b).

Final prosthesis was constructed using the previous index for artificial teeth arrangement ${ }^{(20,21)}$. A full acrylic denture base was constructed for all patients except one, whom received a combined metal \& acrylic base (due to space limitations). During the waxing up procedure, the palatal extension was kept to a minimum (rougee area coverage) with engaging the mesio-palatal angel of canines and a custom labial extension either full vestibular (for average or short lip patients) or partial extension (for prominent labial undercut in normal lip length patients).

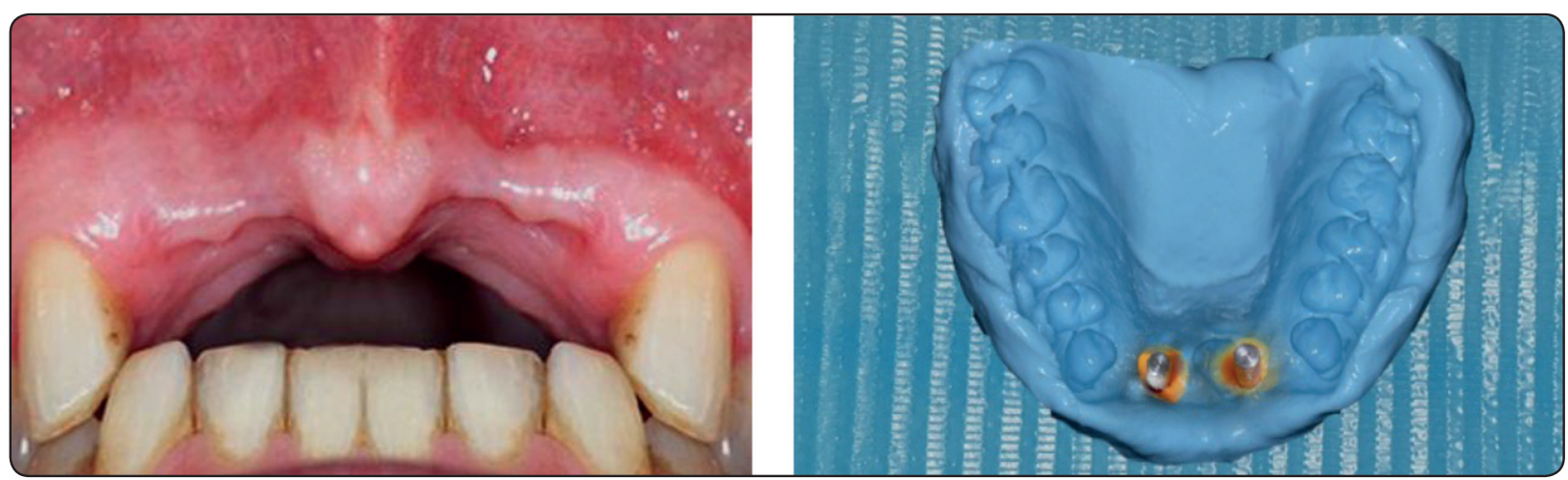

Fig. (1) a) pre-operative anterior partial edentulous maxilla (Kennedy class IV) opposing mandibular dentulous arch, b) final impression with attached implant analogs.

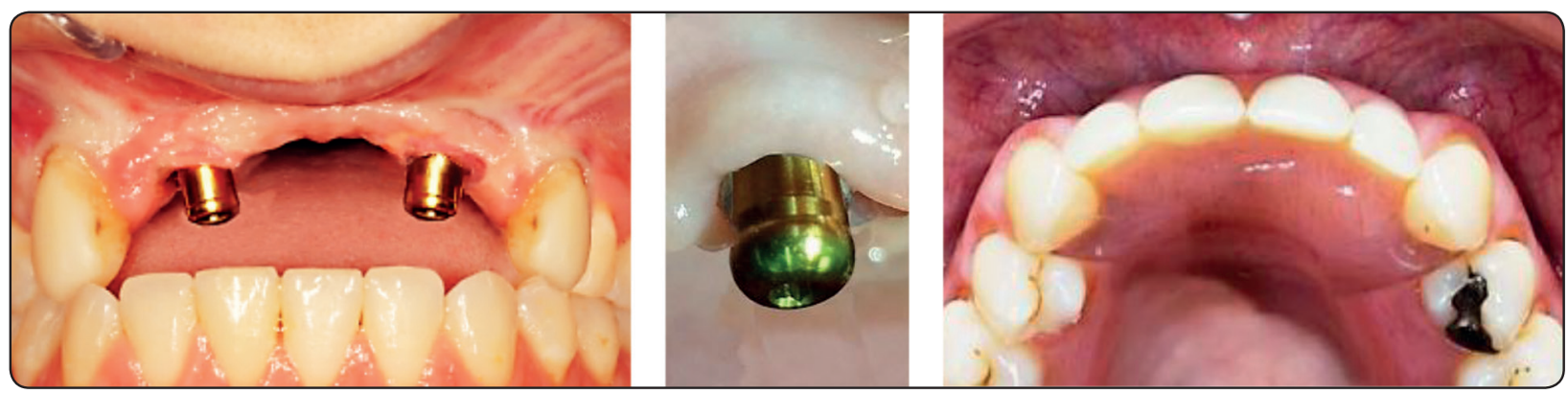

Fig. (2) a) positioner attachment in place, b) positioner and associated surrounding tissues (close-up), c) prosthesis seated in situ after delivery. 
In the laboratory, the attachments were included in prosthesis by indirect technique according to the patients' group; group A (GA), the metal socket of width $5.2 \mathrm{~mm}$, height $2.3 \mathrm{~mm}$ and extended range orange plastic socket female with tilting angle $\pm 10^{\circ}$ and 500gf, group B (GB) Metal socket of width 4.05 , height $2.9 \mathrm{~mm}$ and $15^{\circ}$ degree tilting angle freedom with mini O-ring 300 500gf).

Also, a plastic x-ray holder (Dentsply, Rinn Corporation, Elgin, IL, USA) was custom modified by rubber base heavy body impression for each case to contain a female attachment matrix embedded-in for radiographic standardization.

On prosthesis delivery appointment the healing abutments were removed and the site was cleaned using chlorohexidine solution then attachments were screwed at $25-30 \mathrm{Ncm}$ torque ${ }^{(22)}$ using a torque indicating ratchet and a per-apical radiograph was used to confirm adaptation of attachment on the implant ${ }^{(23)}$.
The final prosthesis was delivered to all patients with necessary adjustments and freeing occlusion in all directions (fig. 2a,3a). Patients' satisfaction from the esthetic and phonetic aspect and prosthesis retention was assured and follow-up was scheduled.

\section{Data collection}

Using the modified x-ray holder, sequential digital periapical radiographs were taken at the time final prosthesis insertion (T0), 6months (T6), and 12 months (T12) (figure 4a, b, c). Radiographs were inspected for crestal bone changes (in terms of the difference between bone crest and implant margin as a reference point) by 2 independent examiners ${ }^{(24)}$. Magnification difference was calculated based on the actual distance between two threads ${ }^{(25)}(0.4 \mathrm{~mm}$ according to the implant manual (Implantum II, Dentium Co., Seoul, Korea) then the mesial and distal measurements on both sides were averaged (sum/4) to represent the patient.

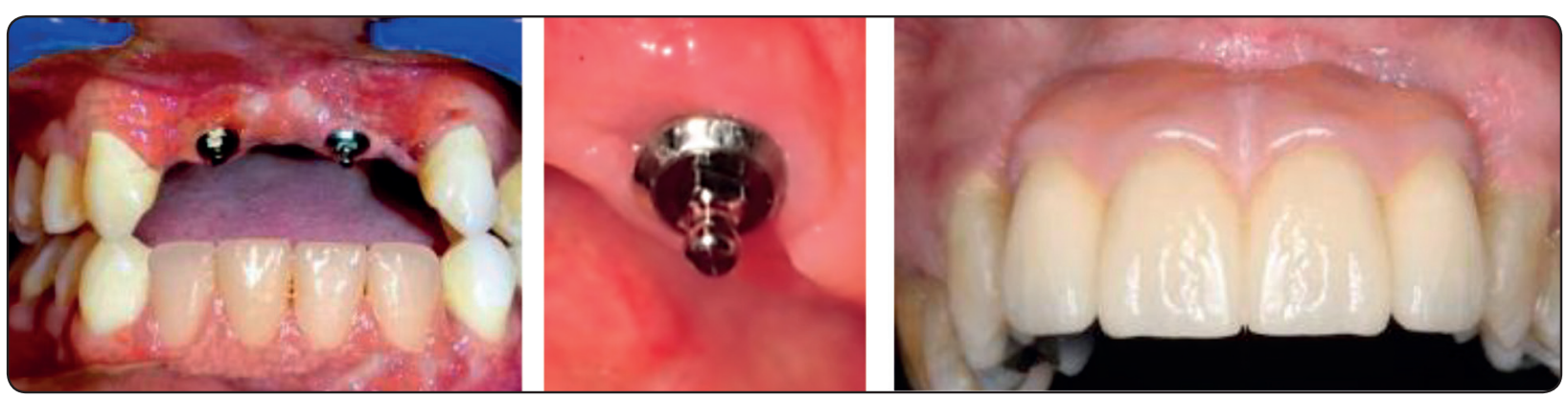

Fig. (3) a) ball attachment attachment in place, b) ball and associated surrounding tissues (close-up), c) prosthesis seated in situ after delivery.

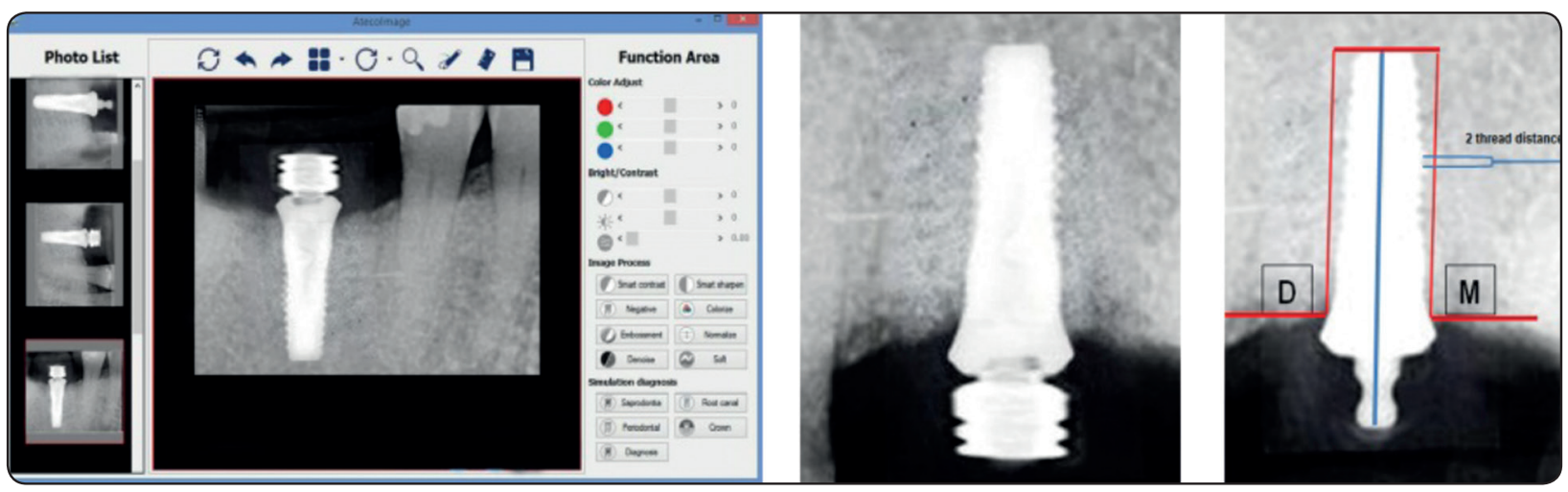

Fig. (4) a) implant radiographic image with ball abutment, b) implant with ball attachment and its socket as part of the stent, c) demonstrative tracing lines for measuring marginal bone level . 
Patient satisfaction was assessed with a 6-item questionnaire in a meter-shaped visual analog scale (VAS) to determine the benefits of the implant-supported prosthesis (IP) over the conventional partial removable prosthesis $(\mathrm{CP})$. The questionnaire was submitted the day of the patient inclusion and 3 months after implant placement. Items were evaluated with $1 \sim 10$ range scores ( $1=$ very dissatisfied to $10=$ very satisfied).

Tissue health integrity as presented in the gingival index (GI) and peri-implant propping depth (PD) ${ }^{(26,27,28)}$ was followed up on all implant aspects at delivery, 6 months, and 12-month period. Also, the resonance frequency analysis was used to verify implant stability by Osstell (RFA, Osstell AB, Gothenburg, Sweden) at same time intervals.

\section{Statistical analysis}

Data were processed in SPSS (Statistical Package for Social Science) using Mann-Whitney U-test, Wilcoxon's signed-rank test, and Kruskal Wallis H-test to test the homogenous non-parametric radiographic and clinical variables, and to calculate the confidence interval.

\section{RESULTS}

Eight participants were selected enrolled in this study with no withdrawals. The results of VAS comparing patient response after treatment showed a significant difference regarding all items except regarding hygiene care which showed nonsignificant difference (table 2).

Over the relatively short study period, no implant failures were recorded with a success rate of $100 \%$ and a mean marginal bone loss of $0.66 \pm 0.10$ in GA and $0.70 \pm 0.09$ in GB. Periods showed a significant increase in each group with non-significant between groups (table 3).

Both Gingival probing depth (PD) and gingival index (GI) shown a significant increase through study periods and significant differences between groups. Also comparing implant stability readings (IS) was insignificant between groups but only significant between different periods in GB (table 4,5,6).

TABLE (2) Comparison of VAS results for all patient before \& after prosthesis.

\begin{tabular}{|c|c|c|c|}
\hline \multirow{2}{*}{ Questions } & VAS score (BIP) & VAS score (AIP) & Statistics* \\
\hline & $\mathrm{X} \pm \mathrm{SD}(95 \% \mathrm{CI})$ & $\mathrm{X} \pm \mathrm{SD}(95 \% \mathrm{CI})$ & $\mathrm{P}$ \\
\hline Are you generally satisfied with your prosthesis? & $\begin{array}{l}67.50 \pm 4.63 \\
61.92 \text { to } 70.58\end{array}$ & $\begin{array}{c}92.00 \pm 7.07 \\
86.58 \text { to } 98.42\end{array}$ & $0.007 * *$ \\
\hline $\begin{array}{l}\text { Are you satisfied with the retention \& stability of your } \\
\text { prosthesis? }\end{array}$ & $\begin{array}{c}61.25 \pm 8.35 \\
54.27 \text { to } 68.23\end{array}$ & $\begin{array}{c}91.25 \pm 6.41 \\
85.89 \text { to } 96.61\end{array}$ & $0.011 * *$ \\
\hline $\begin{array}{l}\text { Does your prosthesis affect } \\
\text { your speaking abilities? }\end{array}$ & $\begin{array}{c}65.00 \pm 10.69 \\
56.06 \text { to } 73.94\end{array}$ & $\begin{array}{c}92.50 \pm 7.07 \\
86.58 \text { to } 98.42\end{array}$ & $0.009 * *$ \\
\hline $\begin{array}{l}\text { Are you satisfied with the general appearance of your } \\
\text { prosthesis? }\end{array}$ & $\begin{array}{l}70.00 \pm 7.56 \\
63.68 \text { to } 76.32\end{array}$ & $\begin{array}{c}90.00 \pm 7.56 \\
83.68 \text { to } 96.32\end{array}$ & $0.015^{* *}$ \\
\hline Is it difficult to clean your prosthesis? & $\begin{array}{l}67.50 \pm 8.86 \\
60.09 \text { to } 74.91\end{array}$ & $\begin{array}{l}67.50 \pm 4.63 \\
63.63 \text { to } 71.37\end{array}$ & 0.062 \\
\hline Are you generally satisfied with your oral condition? & $\begin{array}{c}53.75 \pm 7.44 \\
47.53 \text { to } 59.97\end{array}$ & $\begin{array}{c}85.00 \pm 9.26 \\
77.26 \text { to } 92.74\end{array}$ & $0.009 * *$ \\
\hline
\end{tabular}

$B I P=B$ efore implant placement, $A I P=A$ fter implant placement, Number of variables $(n=8), X=m e a n, S . D=$ standard deviation, $C I=A t 95 \%$ confidence interval, $*$ Wilcoxon Signed rank test, $* * P=$ significant at $<0.05$. 
TABLE (3) Comparison between and within groups, in implant marginal bone changes (in millimeters) at different scheduled observation periods .

\begin{tabular}{|c|c|c|c|c|}
\hline $\begin{array}{l}\text { Time } \\
\text { Group }\end{array}$ & T0 & T6 & $\mathrm{T} 12$ & $\begin{array}{l}\text { Wilcoxon's signed-rank test } \\
\text { (P-value) }\end{array}$ \\
\hline $\mathrm{GA}(\mathrm{X} \pm \mathrm{SD})$ & $0.15 \pm 0.05$ & $0.58 \pm 0.09$ & $0.66 \pm 0.10$ & $.023^{*}, .020 *$ \\
\hline $\mathrm{GB}(\mathrm{X} \pm \mathrm{SD})$ & $0.11 \pm 0.04$ & $0.63 \pm 0.08$ & $0.70 \pm 0.09$ & $.024 *, .013^{*}$ \\
\hline Mann-Whitney test (P-value) & 0.114 & 0.146 & 0.341 & \\
\hline
\end{tabular}

$G A=$ positioner group,$G B=$ ball group, $X=$ mean; $S D=$ standard deviation, *Significant at 0.05 level .

TABLE (4) Comparison between and within groups, in gingival probing depth (PD) in millimeters at different scheduled observation periods.

\begin{tabular}{|c|c|c|c|c|c|c|c|c|}
\hline & & M & SD & & Max & $\begin{array}{c}\text { Comparison within group } \\
\text { Kruskal Wallis H-test }\end{array}$ & \multicolumn{2}{|c|}{$\begin{array}{c}\text { Comparison between groups } \\
\text { Mann-Whitney test }\end{array}$} \\
\hline & T0 & 0.0 & 0.0 & 0.0 & 0.0 & & \multirow{6}{*}{$\begin{array}{l}\text { At } \mathrm{T} 6 \\
\text { At } \mathrm{T} 12\end{array}$} & \\
\hline \multirow[t]{3}{*}{ GA } & T6 & 2.5 & 0.18 & 2.1 & 2.80 & $.000 ¥, .000 ¥$ & & \\
\hline & $\mathrm{T} 12$ & 3.5 & 0.18 & 3.2 & 3.90 & & & .071 \\
\hline & T0 & 0.0 & 0.0 & 0.0 & 0.0 & & & .061 \\
\hline \multirow[t]{2}{*}{ GB } & T6 & 2.3 & 0.13 & 2.1 & 2.60 & \multirow[t]{2}{*}{$.000 ¥, .000 ¥$} & & \\
\hline & $\mathrm{T} 12$ & 3.2 & 0.17 & 3.0 & 3.50 & & & \\
\hline
\end{tabular}

$M=$ mean, $S D=$ standard deviation, $¥=$ level of significance $(\leq 0.05), N S=$ insignificant

(T0)= at delivery, $($ T6 $)=$ after 6 month , (T12)= after 12 month.

TABLE (5) Comparison between and within groups, in gingival index (GI) at different scheduled observation periods.

\begin{tabular}{|c|c|c|c|c|c|c|c|}
\hline & & M & \multicolumn{2}{|c|}{ Min - Max } & $\begin{array}{c}\text { Comparison within group } \\
\text { Kruskal Wallis H-test }\end{array}$ & \multicolumn{2}{|c|}{$\begin{array}{c}\text { Comparison between groups } \\
\text { Mann-Whitney test }\end{array}$} \\
\hline & T0 & 0.0 & 0.00 & 0.00 & & \multirow{6}{*}{$\begin{array}{l}\text { At } \mathrm{T} 6 \\
\text { At } \mathrm{T} 12\end{array}$} & \\
\hline \multirow[t]{3}{*}{ GA } & T6 & 2.5 & 0.00 & 3.00 & $.000 ¥, .000 ¥$ & & \\
\hline & $\mathrm{T} 12$ & 3.5 & 0.00 & 3.00 & & & .151 \\
\hline & T0 & 0.0 & 0.00 & 0.00 & & & $.011 ¥$ \\
\hline \multirow[t]{2}{*}{ GB } & T6 & 1.00 & 0.00 & 3.00 & $.000 ¥, .000 ¥$ & & \\
\hline & $\mathrm{T} 12$ & 2.00 & 0.00 & 3.00 & & & \\
\hline
\end{tabular}

$M=$ median, Min= minimum Max= maximum, $¥=$ level of significance $(\leq 0.05), N S=$ insignificant, $(0)=$ at delivary, $(6)=$ after 6 month, (12)= after 12 month. 
TABLE (6) Comparison between implant stability readings (IS) at different scheduled observation periods.

\begin{tabular}{|c|c|c|c|c|c|c|c|}
\hline & & $\mathrm{M}$ & SD & \multicolumn{2}{|c|}{$\begin{array}{c}\text { Range } \\
\text { Min - Max }\end{array}$} & \multirow{2}{*}{$\begin{array}{c}\begin{array}{c}\text { Comparison within group } \\
\text { Kruskal Wallis H-test }\end{array} \\
.000 ¥\end{array}$} & $\begin{array}{l}\text { Comparison between groups } \\
\text { Mann-Whitney test }\end{array}$ \\
\hline & $\mathrm{T} 0$ & 69.15 & $1.00 \pm$ & 69.0 & 70.0 & & \multirow{6}{*}{$\begin{array}{ll}\text { At T6 } & .211 \\
\text { At T12 } & .073\end{array}$} \\
\hline \multirow[t]{3}{*}{ GA } & T6 & 71.25 & $2.00 \pm$ & 70.0 & 73.0 & $.000 ¥$ & \\
\hline & $\mathrm{T} 12$ & 71.75 & $0.75 \pm$ & 71.0 & 74.0 & $.000 ¥$ & \\
\hline & T0 & 69.15 & $1.00 \pm$ & 69.0 & 70.0 & NS & \\
\hline \multirow[t]{2}{*}{ GB } & T6 & 70.33 & $0.33 \pm$ & 70.0 & 71.0 & NS & \\
\hline & $\mathrm{T} 12$ & 70.33 & $0.33 \pm$ & 70.0 & 71.0 & NS & \\
\hline
\end{tabular}

$M=$ mean, $S D=$ standard deviation, $¥=$ level of significance $(\leq 0.05), N S=$ insignificant

$($ T0 $)=$ at delivery, $($ T6 $)=$ after 6 month,$($ T12 $)=$ after 12 month.

\section{DISCUSSION}

For implant-supported reconstruction to gain success with optimal esthetics, prosthodontics should target a visually pleasing restoration and healthy surrounding soft tissue.

Temporary acrylic partial removable prosthesis relined with soft lining material was used for 8 weeks ${ }^{(29,30,31)}$ thus the final prosthesis was delivered within 3 months. The temp may offered a kind of progressive loading while the final prosthesis delay was aiming to avoid the immediate loading in that area (due to the bone type) thus the risk of implant failure or at least the crestal bone loss were minimized ${ }^{(32,33)}$. Loading maxillary bone was reported 6 months in many reports, but also early loading from 8-12 weeks was reported with comparable results to the conventional type ${ }^{(34,35)}$.

Patient satisfaction is the main target and according to VAS the patients have shown general expected satisfaction due to a decrease in restoration extension and absence of metallic clasping in addition to tongue freedom in movement and normal palatal contact without barriers ${ }^{(36-39)}$.

The used types of prosthetic attachments offer a mechanical source of retention that secure denture in place without visible clasping, which in turn give more aesthetics and decrease the possible caries risk on neighboring natural teeth ${ }^{(40)}$.

Difficulty in cleaning underneath was not reported but some difficulty with hygiene steps around attachments was shown in the beginning. Within the first 1-2 months that was resolved may be due to the presence of attachments in a visible accessible area or the less complicated attachment design, and according to VAS that did not statistically affect the patient acceptance of their prosthesis ${ }^{(41-43)}$.

Over the relatively short study period, no implant failures were recorded with a success rate of $100 \%$ according to reported criteria ${ }^{(44,45)}$, and a mean marginal bone loss comparable to clinical reports ${ }^{(46)}$, a marginal bone change of $0.66 \pm 0.10$ in GA and $0.70 \pm 0.09$ in GB was shown in table 2 with a non-significant statistical difference between groups.

Points considered in this study, such as freedom of contacts in eccentric jaw movements, were aiming to avoid the force moments on implants and surrounding bone especially in the anterior region where the bone angulation renders the force direction on implants inevitably non-perpendicular ${ }^{(47,48)}$. Possibly the relatively short profile attachment had a role in decreasing non-acceptable forces due to 
innate stress breaking design and the relatively decreased abutment implant ratio in both groups ${ }^{(49-52)}$.

Upon biting the prosthetic teeth incisal edges will bear forces analyzed in upward and forward components. Their fulcrum in the attachment while their arm equals the distance from incisal edge to the attachment level ${ }^{(53,54,55)}$. The base engaging mesio-palatal angel of canines and the small palatal extension may have contributed to counteract these forces. The relatively small changes in bone level may support this vision.

According to Keshk, et al ${ }^{(56)}$, the bone changes were non-significant between most solitary attachments, especially on short clinical trials. These results were highlighted in another study ${ }^{(57)}$ testing the stress distribution of different solitary attachments and it agrees with the results of this study. Ball attachment was reported to deliver more stress to investing bone only with increase abutment length ${ }^{(58)}$ or abutment gingival height which was not used in this work.

For the soft tissue parameters, usually, the periimplant soft tissue health underneath overdenture is critical as it depends on the regularity of oral hygiene measures by the patient ${ }^{(59)}$. Despite the ease of the mission some patients had difficulty in managing this but within 1-2 months this problem was resolved. Also, episodes of gingival overgrowth and inflammation not in the scheduled follow-up visits were recorded but these findings were small in number (one patient with unilateral gingival overgrowth after 3months of final prosthesis insertion in group A \& one with a bilateral gingival inflammation in group B at the same period) and reacted positively to tissue rest (5-7 days use of temporary prosthesis with soft liner), local debridement, and mouthwash. These findings were reported as common in overdenture patients as a response to local hygiene factors ${ }^{(60,61)}$.

The study groups have shown a difference in; the 12 month period in GI in ball attachment cases but no statistical difference was recorded in PD.
Possibly the GI difference can be explained to be related to the bacterial biofilm that is claimed responsible for Peri-implant soft tissue inflammation and is related to the attachment configuration. Mously HA ${ }^{(62)}$ disagrees and according to his work, no statistically significant differences were found in both GI and PD.

According to De Waal et al ${ }^{(63)}$ and Costa et al ${ }^{(64)}$, the plaque around implants supporting overdentures is more persistent than plaque around implants supporting single crowns and partial bridges, because it is less accessible for natural cleaning by the tongue, lip, cheek, and saliva.

PD did not show a significant difference to reflect the GI results which can be referred to the relatively short study period and the implant-abutment connection which is claimed to be protective against an increase in $\mathrm{PD}{ }^{(65,66)}$. Also, these results can be interpreted in terms of local factors reversible effect on GI without permanent loss of peri-implant investing soft or hard tissues ${ }^{(67)}$.

Resonance frequency analysis results showed an overall increase within groups by time which may refer to secondary stability that increases by time ${ }^{(68)}$. Healing and remodeling continuation in the first year are believed responsible for increased implant stability ${ }^{(69,70)}$. Also, an increase in RFA indicates the absence of stresses transferred to the bone surrounding implants ${ }^{(71)}$ and is considered in favor of a good prognosis.

The Osstell measurements were made at final prosthesis insertion (2-3 months after implant installation) and a 3 months implant stability were reported in esthetic zone or (anterior maxilla) to range $68.5-71.0^{(72)}$. The mean age of the patients was $41 \pm 3.4$ years and a change of $13.33 \pm 2.74$ in Osstell value in 3-month healing period for the same age group ${ }^{(73)}$.

The RFA values For a Bone density of 827.96 \pm 206.85 HU (D3), were reported 67.30 $\pm 9.14^{(74)}$. The anterior (pre-maxilla) angulation may also have a role as the Implant angulation in bone also showed 
an effect on RFA values (a mean RFA value of 63.4 in 10o angulation) ${ }^{(75)}$. For a Bone density of $620 \pm$ $251 \mathrm{HU}$ (D3), the RFA value was reported $65.7 \pm 9$ immediately after implant insertion ${ }^{(76)}$. For a Bone density of 594.2 $\pm 95.2 \mathrm{HU}$ (D3), the RFA value was reported 68.4, 69.2, and 70.1 immediately after implant insertion, 6months and 12 months respectively (77).

Two reasons contributed to the limited, brief or even Difficult comparison with other research's results; A) the clinical research usually discussed the use of such attachments in cases of complete overdentures especially in mandible (45,46,4,51,52) , B) the Positioner attachment is less popular, less mentioned in literature than the genuine locator attachment. (both the positioner \& the equator have the same problem). It was mentioned in some case ${ }^{(78)}$ or as preliminary reports that discuss other aspects as; i) prosthesis performance and the masticatory efficiency ${ }^{(79)}$, ii) Masticatory Muscle activity ${ }^{\left({ }^{80}\right)}$, iii) in vitro aiming to study the retention ${ }^{(81)}$, iv) also as a type of attachment within the research but out of the research point focus ${ }^{\left({ }^{82}\right)}, \mathbf{v}$ ) or used and investigated but only concluded from the paper demonstrative figures ${ }^{(24)}$.

\section{CONCLUSION}

Within the limitation of patient number and period of study the following can be concluded;

- Removable partial overdenture can be used (when indicated) in an anterior region with anticipated success taking into consideration the need for stress control and proper oral hygiene

- Different types of attachments did not show a difference in performance but reflected accepted initial results

- Controlling the local peri-implant tissue hygiene is an important key for treatment success

\section{Conflict of interest}

The author declare no conflict of interest.

\section{Financial disclosures}

The author declare that this work had no financial support from any governmental nor private foundation.

\section{REFERENCES}

1. Maló P1, Rangert B, Dvärsäter L. Immediate function of Brånemark implants in the esthetic zone: a retrospective clinical study with 6 months to 4 years of follow-up. Clin Implant Dent Relat Res. 2000;2(3):138-46.

2. Da Silva Salomão GV, Santos FT, Allegrini Junior S. The importance of prosthetic planning for implant-supported dentures in esthetic zones - A case report. Int J Surg Case Rep. 2019;54:15-19.

3. Papaspyridakos P, Tarnow DP, Eckert SE, Weber HP. Replacing Six Missing Adjacent Teeth in the Anterior Maxilla With Implant Prostheses: A Case Series. Compend Contin Educ Dent. 2018 Jun;39(6):e1-e4.

4. Kourtis S, Psarri C, Andritsakis P, Doukoudakis A. Provisional restorations for optimizing esthetics in anterior maxillary implants: a case report. J Esthet Restor Dent. 2007;19:6-18

5. Brugnami F, Caleffi C. Prosthetically driven implant placement. How to achieve the appropriate implant site development. Keio J Med. 2005;54(4):172-178.

6. Askary AS. Multifaceted aspects of implant esthetics: the anterior maxilla. Implant Dent. 2001;10:182-191.

7. Zitzmann NU1, Marinello CP. Treatment plan for restoring the edentulous maxilla with implant-supported restorations: removable overdenture versus fixed partial denture design. J Prosthet Dent. 1999 Aug;82(2):188-96.

8. Délben JA, Goiato MC, Gennari-Filho H, Gonçalves Assunção W, Dos Santos DM. Esthetics in implantsupported prostheses: a literature review. J Oral Implantol. 2012 Dec; 38(6):718-22.

9. de Carvalho WR1, Barboza EP, Caúla AL. Implant-retained removable prosthesis with ball attachments in partially edentulous maxilla. Implant Dent. 2001;10(4):280-4.

10. El-Rashedy Wesam M, Shakal Eman A, El Gendy Mohammed N, Saudi Hussein. Clinical and radiographic evaluation of implant-supported removable partial overdenture in the lower Kennedy class IV cases. 2016; 13(1):1-10 
11. Misch, Carl E. Dental Implant Prosthetics. 2015; P 133-134.

12. Dandekeri SS, Sowmya MK, Bhandary S. Stereolithographic surgical template: a review. J Clin Diagn Res. 2013;7(9):2093-2095.

13. Martinez, H., Davarpanah, M., Missika, P., Celletti, R., \& Lazzara, R. Optimal implant stabilization in low density bone. Clinical Oral Implants Research, 2001. 12(5), 423-432.

14. Munjal S, Munjal S, Hazari P, Mahajan H, Munjal A, Mehta DS. Evaluation of specifically designed implants placed in the low-density jaw bones: A clinico-radiographical study. Contemp Clin Dent. 2015;6(1):40-43.

15. Shadid RM, Sadaqah NR, Othman SA. Does the Implant Surgical Technique Affect the Primary and/or Secondary Stability of Dental Implants? A Systematic Review. Int J Dent. 2014;2014:204838.

16. Bassir SH, El Kholy K, Chen CY, Lee KH, Intini G. Outcome of early dental implant placement versus other dental implant placement protocols: A systematic review and meta-analysis. J Periodontol. 2019 May;90(5):493-506.

17. Degidi M1, Gehrke P, Spanel A, Piattelli A. Syncrystallization: a technique for temporization of immediately loaded implants with metal-reinforced acrylic resin restorations. Clin Implant Dent Relat Res. 2006; 8(3):123-34.

18. Testori T, Del Fabbro M, Feldman S, et al. A multicenter prospective evaluation of 2-months loaded Osseotite implants placedin the posterior jaws: 3-year follow-up results. Clin Oral Implants Res 2002;13:154-161

19. Nordin T, Nilsson R, Frykholm A, Hallman M. A 3-arm study of early loading of rough-surfaced implants in the completelyedentulous maxilla and in the edentulous posterior maxilla and mandible: Results after 1 year of loading. Int J Oral Maxillofac Implants 2004;19:880-886.

20. Cooper L, De Kok IJ, Reside GJ, Pungpapong P, RojasVizcaya F. Immediate fixed restoration of the edentulous maxilla after implant placement. J Oral Maxillofac Surg. 2005 Sep;63(9 Suppl 2):97-110.

21. Dogra M, Kaur J, Pathak A, Brar AS, Sharma A. Aesthetic Replacement of Missing Anterior Teeth Using a Fixed Appliance- An Innovative Technique. Int J Oral Health Med Res 2016;3(1):134-136.

22. Dincer Kose O, Karataslı B, Demircan S, Kose TE, Cene E, Aya SA, Erdem MA, Cankaya AB. In Vitro Evaluation of Manual Torque Values Applied to Implant-Abutment Complex by Different Clinicians and Abutment Screw Loosening. Biomed Res Int. 2017;2017:7376261.
23. Cameron SM, Joyce A, Brousseau JS, Parker MH. Radiographic verification of implant abutment seating. J Prosthet Dent. 1998 Mar;79(3):298-303.

24. Payne AG, Tawse-Smith A, Duncan WD, Kumara R. Conventional and early loading of unsplinted ITI implants supporting mandibular overdentures. Clin Oral Implants Res 2002;13:603-609.

25. Misch CE1, Degidi M. Five-year prospective study of immediate/early loading of fixed prostheses in completely edentulous jaws with a bone quality-based implant system. Clin Implant Dent Relat Res. 2003;5(1):17-28.

26. Mombelli A, van Oosten MA, Schurch E Jr, Land NP. The microbiota associated with successful or failing osseointegratedtitanium implants. Oral Microbiol Immunol. 1987;2:145-151.

27. Meredith N, Alleyne D, Cawley P. Quantitative determination of the stability of the implant-tissue interface using resonance frequency analysis. Clin Oral Implants Res. 1996;7:261-267.

28. Glauser R, Sennerby L, Meredith N, Ree A, Lundgren A, Gottlow $\mathrm{J}$ et al. Resonance frequency analysis of implants subjected to immediate or early functional occlusal loading. Successful vs. failing implants. Clin Oral Implants Res. 2004;15:428-434.

29. Berberi AN, Noujeim ZN, Kanj WH, Mearawi RJ, Salameh ZA. Immediate placement and loading of maxillary singletooth implants: a 3-year prospective study of marginal bone level. J Contemp Dent Pract. 2014 Mar 1;15(2):202-8.

30. Huang L, Zhang X, Mo A. A Retrospective Study on the Transferring Accuracy of a Fully Guided Digital Template in the Anterior Zone. Materials (Basel). 2021 Aug 17; 14(16):4631.

31. Lindeboom JA, Frenken JW, Dubois L, Frank M, Abbink I, Kroon FH. Immediate loading versus immediate provisionalization of maxillary single-tooth replacements: a prospective randomized study with BioComp implants. J Oral Maxillofac Surg. 2006 Jun;64(6):936-42.

32. Susarla SM, Chuang SK, Dodson TB. Delayed versus immediate loading of implants: survival analysis and risk factors for dental implant failure. J Oral Maxillofac Surg. 2008 Feb;66(2):251-5.

33. Erakat MS, Chuang SK, Yoo RH, Weed M, Dodson TB. Immediate loading of splinted locking-taper implants: 1-year survival estimates and risk factors for failure. Int J Oral Maxillofac Implants. 2008 Jan-Feb;23(1):105-10. 
34. Sun L, Yang MM, Zhao JM, Zhang X, Qu Z. [Analysis of the hard and soft tissue following immediate and early implant placement in the anterior area of maxilla]. Zhonghua Kou Qiang Yi Xue Za Zhi. 2020 Nov 9;55(11):857-863. Chinese.

35. Zembic A, Tahmaseb A, Jung RE, Wismeijer D. Oneyear results of maxillary overdentures supported by 2 titanium-zirconium implants - implant survival rates and radiographic outcomes. Clin Oral Implants Res. 2017 Jul;28(7):e60-e67.

36. Shala KS, Dula LJ, Pustina-Krasniqi T, Bicaj T,Ahmedi EF, Lila-Krasniqi Z, Tmava-Dragusha A. Patient's Satisfaction with Removable Partial Dentures: A Retrospective Case Series. Open Dent J. 2016 Dec 9;10:656-663.

37. Graham R., Mihaylov S., Jepson N., Allen P.F., Bond S. Determining need for a removable partial denture: a qualitative study of factors that influence dentist provision and patient use. Br. Dent. J. 2006;200(3):155-158.

38. Bilhan H., Erdogan O., Ergin S., Celik M., Ates G., Geckili O. Complication rates and patient satisfaction with removable dentures. J. Adv. Prosthodont. 2012;4(2):109115 .

39. Singh K, Gupta N. Palateless custom bar supported overdenture: a treatment modality to treat patient with severe gag reflex. Indian J Dent Res. 2012 MarApr;23(2):145-8.

40. Behr M, Zeman F, Passauer T, Koller M, Hahnel S, Buergers R, Lang R, Handel G, Kolbeck C. Clinical performance of cast clasp-retained removable partial dentures: a retrospective study. Int J Prosthodont. 2012 Mar-Apr;25(2):138-44.

41. Kuoppala R, Näpänkangas R, Raustia A. Outcome of implant-supported overdenture treatment--a survey of 58 patients. Gerodontology. 2012 Jun;29(2):e577-84.

42. Jofre J, Castiglioni X, Lobos CA. Influence of minimally invasive implant-retained overdenture on patients' quality of life: a randomized clinical trial. Clin Oral Implants Res. 2013 Oct;24(10):1173-7.

43. Boven GC, Meijer HJA, Vissink A, Raghoebar GM. Maxillary implant overdentures retained by use of bars or locator attachments: 1-year findings from a randomized controlled trial. J Prosthodont Res. 2020 Jan;64(1):26-33.

44. Albrektsson, T.; Zarb, G.; Worthington, P.; Eriksson, A. The long-term efficacy of currently used dental implants:
A review and proposed criteria of success. Int. J. Oral Maxillofac. Implants 1986, 1, 11-25.

45. Buser, D.; Weber, H.; Lang, N. Tissue integration of nonsubmerged implants. 1-year results of a prospective study with 100 ITI hollow-cylinder and hollow-screw implants. Clin. Oral Implants Res. 1990, 1, 33-40.

46. Bassir SH, El Kholy K, Chen CY, Lee KH, Intini G. Outcome of early dental implant placement versus other dental implant placement protocols: A systematic review and meta-analysis. J Periodontol. 2019 May;90(5):493506.

47. Isidor F. Influence of forces on peri-implant bone. Clin Oral Implants Res. 2006 Oct;17 Suppl 2:8-18.

48. De Smet E, van Steenberghe D, Quirynen M, Naert I. The influence of plaque and/or excessive loading on marginal soft and hard tissue reactions around Brånemark implants: a review of literature and experience. Int J Periodontics Restorative Dent. 2001 Aug;21(4):381-93.

49. Lai HC, Si MS, Zhuang LF, Shen H, Liu YL, Wismeijer D. Long-term outcomes of short dental implants supporting single crowns in posterior region: a clinical retrospective study of 5-10 years. Clin Oral Implants Res. 2013 Feb;24(2):230-7.

50. Malchiodi L, Cucchi A, Ghensi P, Consonni D, Nocini PF. Influence of crown-implant ratio on implant success rates and crestal bone levels: a 36-month follow-up prospective study. Clin Oral Implants Res. 2014 Feb;25(2):240-51.

51. Hong HR, Pae A, Kim Y, Paek J, Kim HS, Kwon KR. Effect of implant position, angulation, and attachment height on peri-implant bone stress associated with mandibular twoimplant overdentures: a finite element analysis. Int J Oral Maxillofac Implants. 2012 Sep-Oct;27(5):e69-76.

52. Yang TC, Maeda Y, Gonda T, Kotecha S. Attachment systems for implant overdenture: influence of implant inclination on retentive and lateral forces. Clin Oral Implants Res. 2011 Nov;22(11):1315-9.

53. Rangert B, Jemt T, Jörneus L. Forces and moments on Branemark implants. Int J Oral Maxillofac Implants. 1989 Fall;4(3):241-7.

54. Vela-Nebot X, Méndez-Blanco V, Rodríguez-Ciurana X, Segalá-Torres M, Gil-Lozano JA. Implant positioning when replacing the four maxillary incisors: a platformswitched treatment option. Int J Periodontics Restorative Dent. 2011 Jul-Aug;31(4):375-81. 
55. Papaspyridakos P, Tarnow DP, Eckert SE, Weber HP. Replacing Six Missing Adjacent Teeth in the Anterior Maxilla With Implant Prostheses: A Case Series. Compend Contin Educ Dent. 2018 Jun;39(6):e1-e4.

56. Keshk AM, Alqutaibi AY, Algabri RS, Swedan MS, Kaddah A. Prosthodontic maintenance and peri-implant tissue conditions for telescopic attachment-retained mandibular implant overdenture: Systematic review and meta-analysis of randomized clinical trials. Eur J Dent. 2017 Oct-Dec;11(4):559-568.

57. Cicciù M, Cervino G, Milone D, Risitano G. FEM Analysis of Dental Implant-Abutment Interface Overdenture Components and Parametric Evaluation of Equator ${ }^{\circledR}$ and Locator ${ }^{\circledR}$ Prosthodontics Attachments. Materials (Basel). 2019 Feb 16;12(4):592

58. KhuranaN, Rodrigues S,Shenoy S, SaldanhaS,PaiU, Shetty T, N S, Mahesh M, Hegde P. A Comparative Evaluation of Stress Distribution with Two Attachment Systems of Varying Heights in a Mandibular Implant-Supported Overdenture: A Three-Dimensional Finite Element Analysis. J Prosthodont. 2019 Feb;28(2):e795-e805.

59. Meijer HJ, Raghoebar GM, de Waal YC, Vissink A. Incidence of peri-implant mucositis and peri-implantitis in edentulous patients with an implant-retained mandibular overdenture during a 10-year follow-up period. J Clin Periodontol. 2014 Dec;41(12):1178-83..

60. Porras R, Anderson GB, Caffesse R, Narendran S, Trejo PM. Clinical response to 2 different therapeutic regimens to treat peri-implant mucositis. J Periodontol. 2002 Oct;73(10):1118-25.

61. Jepsen S, Berglundh T, Genco R, Aass AM, Demirel K, Derks J, Figuero E, Giovannoli JL, Goldstein M, Lambert F, Ortiz-Vigon A, Polyzois I, Salvi GE, Schwarz F, Serino G, Tomasi C, Zitzmann NU. Primary prevention of periimplantitis: managing peri-implant mucositis. J Clin Periodontol. 2015 Apr;42 Suppl 16:S152-7.

62. Mously HA. Effect of Two Implant-supported Partial Overdenture Attachment Design on the Periodontal Health. J Contemp Dent Pract. 2020 Jan 1;21(1):68-72.

63. de Waal YC, van Winkelhoff AJ, Meijer HJ, Raghoebar GM, Winkel EG. Differences in peri-implant conditions between fully and partially edentulous subjects: a systematic review. J Clin Periodontol. 2013 Mar;40(3):266-86.

64. Costa FO, Takenaka-Martinez S, Cota LO, Ferreira SD, Silva GL, Costa JE. Peri-implant disease in subjects with and without preventive maintenance: a 5-year follow-up. J Clin Periodontol. 2012 Feb;39(2):173-81.

65. Roos-Jansåker AM. Long time follow up of implant therapy and treatment of peri-implantitis. Swed Dent J Suppl. 2007;(188):7-66.

66. Sanz-Esporrin J, Carral C, Blanco J, Sanz-Casado JV, Muñoz F, Sanz M. Differences in the progression of experimental peri-implantitis depending on the implant to abutment connection. Clin Oral Investig. 2020 Nov 12.

67. Prathapachandran J, Suresh N. Management of periimplantitis. Dent Res J (Isfahan). 2012 Sep;9(5):516-21.

68. Chen MH, Lyons K, Tawse-Smith A, Ma S. Resonance Frequency Analysis in Assessing Implant Stability: A Retrospective Analysis. Int J Prosthodont. 2019 Jul/Aug; 32(4):317-326.

69. Berglundh T, Abrahamsson I, Lang NP, Lindhe J. De novo alveolar bone formation adjacent to endosseous implants. Clin Oral Implants Res 2003;14:251-262.

70. Raghavendra S, Wood MC, Taylor TD. Early wound healing around endosseous implants: A review of the literature. Int J Oral Maxillofac Implants 2005;20:425-431.

71. Glauser R, Sennerby L, Meredith N, Rée A, Lundgren A, Gottlow J, Hämmerle CH. Resonance frequency analysis of implants subjected to immediate or early functional occlusal loading. Successful vs. failing implants. Clin Oral Implants Res. 2004 Aug;15(4):428-34.

72. Sanchez-Perez A, Nicolas-Silvente AI, Sanchez-Matas C, Molina-García S, Navarro-Cuellar C, Romanos GE. Primary stability and PES/WES evaluation for immediate implants in the aesthetic zone: a pilot clinical double-blind randomized study. Sci Rep. 2021 Oct 8;11(1):20024.

73. Prawoko SS, Nelwan LC, Odang RW, Kusdhany LS. Correlation between radiographic analysis of alveolar bone density around dental implant and resonance frequency of dental implant. InJournal of Physics: Conference Series 2017 Aug 1 (Vol. 884, No. 1, p. 012055).

74. Youssef M, Shaaban AM, Eldibany R. The correlation between bone density and implant stability. Alexandria Dental Journal. 2015 Jul 1;40(1):15-21.

75. Kashi A, Gupta B, Malmstrom H, Romanos GE. Primary stability of implants placed at different angulations in artificial bone. Implant Dent. 2015 Feb;24(1):92-5. 
76. Turkyilmaz I, McGlumphy EA. Influence of bone density on implant stability parameters and implant success: a retrospective clinical study. BMC Oral Health. 2008 Nov $24 ; 8: 32$.

77. Sreerama R, Kolluru KC, Gottumukkala V, Innampudi CK, Konathala JR, Krishnaveni G. Assessment of the Effect of Bone Density on Implant Stability: A Clinical Study. J Pharm Bioallied Sci. 2021 Jun;13(Suppl 1):S297-S300.

78. Beyabanaki E, Alikhasi M. Restoring a Partial Maxillectomy Patient by an Implant-Supported Obturator on Two Implants: A Case Report. J Dent (Tehran). 2018 May;15(3):187-192.

79. Hauck KE, Trentin MS, Skiba THI, Shibli JA, De Carli JP. Clinical and satisfaction outcomes of using one or two dental implants for mandibular overdentures: preliminary short-term follow-up of a randomized clinical trial. Int $\mathbf{J}$ Implant Dent. 2021 Feb 11;7(1):10.

80. Abdelhamid AM, Metwally NA, Imam MH. The effect of two different attachments with implant retained mandibular overdentures on the masticatory function. J Dent Health Oral Disord Ther. 2016;4(2):38-45.

81. Ebiary, Mohamed Hassan, Lubna Eldidi, and Ahmed AbdelHakim. "comparative study of bar, positioner and ball attachment in solitary versus splinted implant assisted mandibular overdenture (in vitro study)." Alexandria Dental Journal (2021).

82. Mourad KE, Emera RM, Ahmed W, Habib A. Lateral incisors versus canine areas for two implant placements used to retain mandibular overdenture: Periodic monitoring of ridge base contact relation. Journal of Dental Implants. 2020 Jul 1;10(2):72. 